\title{
Biological Breakdown Efficiency Research of Wavy Lamellar Structure Air Purification Biofilter with a Capillary Load Moistening System
}

\author{
Pranas Baltrènas, Alvydas Zagorskis, Antonas Misevičius \\ Department of Environment Protection, Vilnius Gediminas Technical University, \\ Sauletekio ave 11, Vilnius 10223, Lithuania
}

\begin{abstract}
Studies were conducted by employing a new generation lamellar structure laboratory air purification device - a biofilter, capable of purifying airflow, polluted with gaseous pollutants. The internal structure of the biofilter is unique in that the bioload, upon which microorganisms dwell and propagate, is fitted onto uprightly arranged wavy lamellas - a layout that creates a capillary moistening effect. Thermally treated birch wood fibers and non-woven caulked materials were used as the bioload in order to increase durability of the load. This paper discusses the results of studies, performed to determine the efficiency of acetone, xylene and ammonia's biological breakdown processes. The conducted research revealed high efficiency of biological breakdown processes. With the acetone fumes concentration of $0,3 \mathrm{~g} \mathrm{~m}^{-3}$ running through the biofilter load at the velocity of $0,08 \mathrm{~m} \mathrm{~s}^{-1}$ and with the number of self-contained microorganisms $1,28 \cdot 10^{10} \mathrm{CFU} / \mathrm{cm}^{2}$, the biodegradation efficiency of the contaminant was $94 \%$, with the xylene fumes concentration of $0,3 \mathrm{~g} \mathrm{~m}^{-3}$ running through the biofilter load and the number of self-contained microorganisms $2,45 \cdot 10^{8} \mathrm{cfu} / \mathrm{cm}^{2}$, the efficiency was $87 \%$, and running $0,3 \mathrm{~g} \mathrm{~m}^{-3}$ concentration of ammonia fumes the efficiency was $88 \%$ with the number of self-contained microorganisms of $4,4 \cdot 10^{8} \mathrm{CFU} / \mathrm{cm}^{2}$. Using wavy lamellas with fastened load allows a longer contact time between the pollutant and the bioload compared to flat lamellas.
\end{abstract}

Keywords: biofilter; biodegradation; capillarity; bio-load; wood fiber; VOC; air cleaning.

\begin{tabular}{|ll|}
\hline Nomenclature \\
VOC & volatile organic compounds \\
WPP & wavy polymer plate \\
BWF & birch wood fiber \\
NM & non-woven material \\
\hline
\end{tabular}

\section{Introduction}

The amount of emissions of volatile organic compounds (acetone, xylene) into the atmosphere is much smaller than that of combustion products like $\mathrm{CO}_{2}, \mathrm{CO}, \mathrm{SO}_{2}$ and $\mathrm{NO}_{2}$; however, VOCs have a greater impact on people and the environment [1, $2,3]$. Likewise, increasing amounts of VOCs have a direct impact on climate change, and are linked to the depletion of the ozone layer [4], which makes decontaminating these pollutants an important task for decreasing the negative impact on the environment.

VOC's (acetone, xylene) and ammonia are usually emitted from wastewater treatment plants of most industries, e.g., foundries, the chemical industry, electronics and paint manufacturers, etc [5].

Currently, one of the cheapest, most promising and effective methods of air purification is biological air purification, which exploits certain microorganism cultures that help break down airborne pollutants into harmless fission products through biological destruction $[6,7,8]$.

Certain conditions have to be met for the biological breakdown of pollutants within the biofilter to take place simultaneously with the proliferation of microorganisms. Physical factors that affect the growth and proliferation of microorganisms the most are usually humidity and temperature [9]. Water is the most important environment where the 
metabolism of organisms takes place, besides, every chemical reaction taking place within living microorganisms requires water. Roughly, 75 per cent or even more of the microorganisms' biomass is water.

It is important to ensure control of the load moistening system within the biofilter, because the load moisture changes in the process of purifying the air of VOCs. Flowing through the load, air gets saturated with fumes, removes humidity and decreases the moisture of the load. However, the biological process of decay turns organic compounds into carbon dioxide $\left(\mathrm{CO}_{2}\right)$ and water, restoring some of the moisture [10,11]. Break down of $1 \mathrm{~kg}$ of hydrocarbon yields $1.5 \mathrm{~kg}$ of water. Usually it is not enough and the load has to be moistened additionally. For effective biodegradation of pollutants the moisture content has to be at $40-70 \%[12,13,14]$. The load's moisture depends on its type and the moistening system installed in the biofilter. For the purpose of the current study, the biofilter was fitted with a capillary moistening system, i.e., the medium in the biofilter emerged via pores of non-woven caulked material and birch wood fiber because of the small $(6 \mathrm{~mm})$ gaps between the wavy lamellas. Such moistening system is superior to others as it consumes much less energy and continues to operate at full capacity even when the energy supply is cut off.

Temperature is the most important factor, which determines the proliferation speed of microorganisms and the intensity of biochemical reactions. Various groups of microorganisms are adapted to living in different temperatures. Microorganisms that participate in the biological breakdown of pollutants are divided into three distinct groups - psychrophilic, mesophilic and thermophilic. In our studies, the temperature of the medium and air in the biofilter was kept at $25-30{ }^{\circ} \mathrm{C}$. This temperature range was conducive to the growth and proliferation of mesophilic microorganisms [15, 16].

Contact time of the bioload and the pollutant is yet another important factor for optimal and effective air purification. The slower the velocity of air flow within the biofilter, the longer is the contact time of the bioload and the polluted air, which increases the efficiency of the biological breakdown process.

Another important factor is the $\mathrm{pH}$ value of the environment. Cellular transport mechanisms of microorganisms, reactions, growth rate, breakdown of certain substances and synthesizing of other substances into new compounds all depend on the acidity of the environment, which is expressed by the $\mathrm{pH}$ value. Most microorganisms tolerate the deviation of $\pm 1-2$ from the optimal $\mathrm{pH}$ value [17]. With the change of the medium's reaction, the enzyme activity of heterotrophs changes as well. Biological air purification employs neutral, weakly alkaline or acidic environments, where the concentration of hydrogen ions $(\mathrm{pH})$ can fluctuate between 6 and 8 [18]. Most environments used to decompose volatile organic compounds have a neutral hydrogen ions concentration $(\mathrm{pH}=7)$.

In order to ensure effective biological breakdown process, it is recommended to secure and maintain optimal values of the above-listed parameters within the biofilter.

The aim of the research is to determine the efficiency of biological breakdown by running acetone, xylene and ammoniapolluted air through the device, using a capillary load moistening system, consisting of porous lamellas; to distinguish which microorganisms participate in biological breakdown and determine their number

\section{Materials and methods}

The experimental studies were carried out by using a biological air purification device - a biofilter. The scheme of the biofilter with wavy lamellas is presented in Figure 1. The biofilter consists of the load, a system which maintains the moisture content and temperature of the load within the biofilter, a ventilator, air supply ducts via which air is supplied and removed from the device and airflow regulation valve.

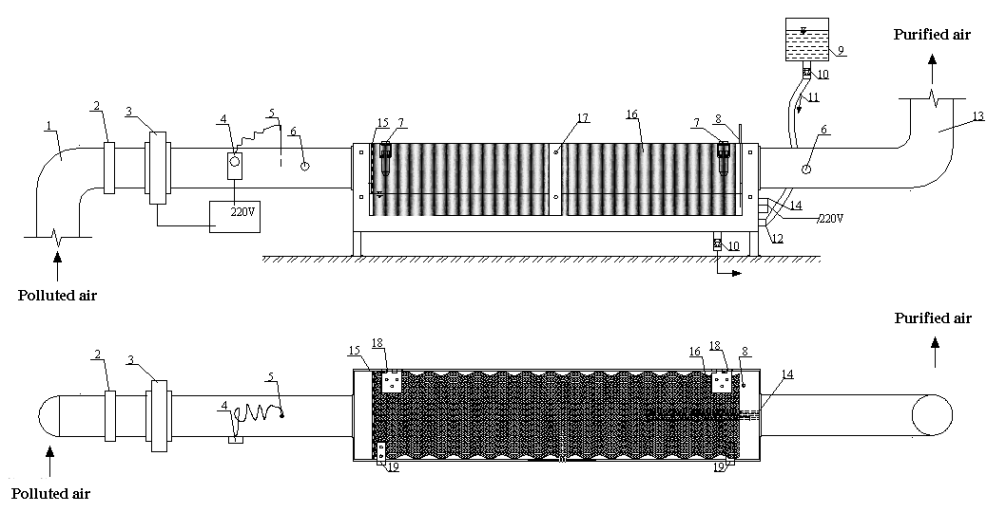

Fig. 1. Lamellar structure wavy air biofilter treatment with capillary irrigation system boot scheme

Polluted air is supplied to the biofilter through a $100 \mathrm{~mm}$ diameter duct for polluted air (1). An air flow that passes through the biofilter is created by a ventilator (3) fitted in the polluted air duct. The valve (2) in the polluted air duct regulates the velocity of air flow and the yield of supplied air. Then the polluted air flows into the cassette of the biofilter (16). The latter is fitted with a load made up of porous lamellas. The air flow is evenly distributed throughout the entire volume of the load via a perforated lamella (15). Polluted air flows between the porous lamellas, which are immersed into a liquid environment and arranged $6 \mathrm{~mm}$ apart from each other. After passing through the biofilter's cassette (16) purified air 
enters a $100 \mathrm{~mm}$ diameter duct for purified air (13) and is expelled into the environment. The cassette is fitted onto the device suing fastening elements (7). Sampling hollows (6) are installed within both polluted and purified air ducts. It is in these measurement points that air flow velocity, temperature and concentrations of pollutants that are fed into and expelled from the biofilter are measured. Surplus biomass is removed from the biofilter through the biomass release valve (10). Proper temperature of the air supply is maintained by a ducted air heater $(18)$ with a thermo-regulator and a sensor $(4,5)$. Temperature of the biomedium is maintained with a biomedium-heating element (14). Biogenic element-saturated solution gets into the biofilter through a specially fitted reservoir (9) with adjustment valves $(10,12)$ and a supply hose (11).

The main element of the biofilter is the cassette made up of wavy lamellas upon which the bioload, i.e., non-woven caulked material and wood fiber, is fitted. The dimensions of the cassette are $900 \times 200 \times 200 \mathrm{~mm}$. The load consists of upright wavy porous lamellas, arranged next to each other and forming a capillary load moistening effect. The lamellas are arranged in $6 \mathrm{~mm}$ intervals. The arrangement and position of the lamellas is presented in Figure 1.

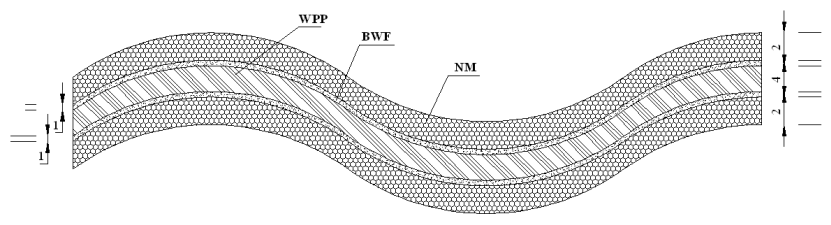

Fig. 2. Porous plate composition (WPP - wavy polymer plate, BWF - birch wood fiber, NM - non-woven material)

Heat-treated birch wood fiber granules are fitted from both sides of the solid, polymer wavy lamella. Heat treatment of the birch wood fiber is imperative in order to maintain its longevity. Birch wood fiber is obtained by treating birch wood cuttings with heat in a steam explosion reactor at 32 bar pressure and $235^{\circ} \mathrm{C}$ temperature. Altering the chemical structure of wood in such way prevents birch wood fiber from rotting in a humid environment, which increases the longevity of the biofilter's load. In order to enhance the capillarity of a lamella and to increase the height of the biomedium, non-woven caulked material is attached onto the birch wood fiber. The dimensions of the porous lamella within the biofilter are $900 \times 200 \times 10 \mathrm{~mm}$. General composition and thickness of the lamella is presented in Figure 2 .

Physical properties of substances used for biological air purification are presented in chart 1.

Table 1. Biological air cleaning materials used in the physical properties

\begin{tabular}{lllll}
\hline Name of substance & $\begin{array}{l}\text { Relative humidity of } \\
\text { material, } \%\end{array}$ & $\begin{array}{l}\text { Absolute humidity of } \\
\text { material, } \%\end{array}$ & Porosity, $\%$ & Density, $\mathbf{g} / \mathrm{cm}^{3}$ \\
\hline Non-woven material & 3,1 & 8,4 & 89,2 & 0,13 \\
\hline Birch wood fiber & 10,6 & 13,3 & 72,0 & 0,14 \\
\hline
\end{tabular}

Relative and absolute moisture content of materials were determined by the weighting method, which is based on mass reduction. Porosity was determined by saturation method and density by weighing method.

The choice of materials was also determined by their inner structure. The structure of materials was determined with an electron microscope. Electronic scanning microscopy was carried out with a field emissions scanning electron microscope JEOL ISM $-7600 \mathrm{~F}$. The microscope magnifies from 25 to 1000000 times. Electron acceleration voltage $-0.1 \mathrm{kV}$ to $30 \mathrm{kV}$. Image resolution - up to $5120 \times 3840$ pixels. The structure of examined materials is presented in Figures 3 and 4.

\section{Moisture content maintenance within a wavy lamellar structure biofilte}

Porous lamellas that constitute the biofilter's cassette are immersed in a biogenic element-saturated solution (Fig. 1). The solution used for present research was made up of: $\mathrm{K}_{2} \mathrm{HPO}_{4}-1 \mathrm{~g}, \mathrm{KCl}-0.5 \mathrm{~g}, \mathrm{MgSO}_{4} \cdot 7 \mathrm{H}_{2} \mathrm{O}-0.5 \mathrm{~g}, \mathrm{FeSO}_{4} \cdot 7 \mathrm{H}_{2} \mathrm{O}-0.1 \mathrm{~g}$, $\mathrm{NaNO}_{3}-0.90 \mathrm{~g}$, distilled water $-1000 \mathrm{~g}[19,20,21,22,23,24,25]$.

Immersion depth of the porous lamellas reached $50 \mathrm{~mm}$. Capillary load moistening effect is due to the porous structure of the lamellas and the size of the gaps between them $(4 \mathrm{~mm})$. During the capillary moistening effect, the solution (biomedium) emerges and moistens the wood fibers and caulked material, which is why this self-contained moistening system does not require additional energy supply. The moisture content of the load is determined with a humidity meter M0290, which operates on the electrical resistance measuring method. The moisture content measurement interval of the device is 0 to $99.9 \%$ and measurement error $- \pm 0.1 \%$. Daily load moisture content measurements were made at different sites of the porous lamellas.

\section{pH of the biomedium and temperature measurement}

Proper $\mathrm{pH}$ and temperature of the biogenic element-saturated solution (biomedium) were maintained by using buffer solutions [26]. $\mathrm{pH}$ was determined according to the LST ISO 10523 standard. 'Mettler Toledo' meter was used to determine $\mathrm{pH}$ and temperature. The device's measurement interval is 0 to 14 and the margin of error is \pm 0.01 . The $\mathrm{pH}$ value and temperature were measured daily. 


\section{Bioload activation and measurement of the biological breakdown efficiency}

Studies were carried out by running acetone, xylene and ammonia-polluted air through the biofilter load. The average air flow velocity between the wavy lamellas was $0.08 \mathrm{~m} / \mathrm{s}$. The velocity was determined and then monitored daily with an air flow meter 'Testo 400', which was equipped with a thermocouple. At the air flow velocity of $0 \mathrm{~m} / \mathrm{s}$ to $2 \mathrm{~m} / \mathrm{s}$, the accuracy of the thermocouple gauge was $\pm 0.01 \mathrm{~m} / \mathrm{s}$.

Bioload activation took 15 days. During the activation air, polluted with acetone fumes was supplied to the biofilter. Average initial concentration of the pollutant was $5.7 \mathrm{mg} / \mathrm{m}^{3}$. Acetone fumes were fed into the device for 15 minutes 4 times a day. The next day, the concentration of the organic compound was increased by $20 \pm 5 \mathrm{mg} / \mathrm{m}^{3}$ and the duration of acetone fumes supply was prolonged to 1 hour. After the activation, biological breakdown efficiency test was carried out for 9 more days, using air, polluted with acetone fumes. Further, xylene was employed as the pollutant, and research was continued by increasing the concentration of xylene fumes fed into the biofilter. The research employing xylene polluted air lasted 9 days. The xylene tests were followed by the ammonia-polluted air tests, during which air contaminated with ammonia fumes was run through the load. Research with ammonia lasted for 10 days.

Efficiency of pollutant biodegradation is calculated by determining the pollutant's concentration before and after running it through the device. Pollutant concentration is determined with 'MiniRae 2000' device with a measurement range from 0 to $7000 \mathrm{mg} / \mathrm{m}^{3}$. When the pollutant's concentration is 0 to $100 \mathrm{mg} / \mathrm{m}^{3}$, accuracy of measurement is $0.1 \mathrm{mg} / \mathrm{m}^{3}$ and when the concentration exceeds $100 \mathrm{mg} / \mathrm{m}^{3}$ it is $1 \mathrm{mg} / \mathrm{m}^{3}$.

\section{Microbiological studies}

In order to determine the number of microorganism and their cultures, microbiological research was conducted simultaneously with the biological breakdown efficiency research. Samples were taken from the bottom, middle and upper parts of a biofilter's lamella every 2-3 days. In total, 39 biofilter load's samples were studied. Microbiological studies on purifying the air of acetone took 29 days, of xylene 9 days and of ammonia 10 days.

The washout (suspension dilution) method was used to separate and count the microorganisms. A $1 \mathrm{~g}$ piece of each sample was put into a flask with $90 \mathrm{ml}$ of $0.8 \% \mathrm{NaCl}$ and proper dilutions were prepared. In order to compare different samples, calculations were made by drying the examined material to a steady weight and calculating the microorganisms count in $1 \mathrm{~g}$ of dry biofilter material. Additionally, the area of the weighed piece is estimated and microorganism count in $1 \mathrm{~cm}^{2}$ is calculated.

Micromycetes were secreted onto a beer must agar-treated environment. Inoculum was incubated in Petri dishes for 5-7 days at $+28^{\circ} \mathrm{C}$.

Pure micromycete cultures were identified by classical methods, used to identify fungi [27, 28]

Yeast cultures were secreted onto Sabouraud's agar with chloramphenicol (Liofilfem, Italy) and Rose Bengal CAF agar (Liofilfem, Italy) nutritional environments. Inoculum was incubated in Petri dishes for 3-4 days at $+28{ }^{\circ} \mathrm{C}$.

Yeast cultures were identified by employing Api 20 C AUX (bioMérieux, France) identification systems.

In order to isolate bacteria from the test samples, nutritional (Nutrient agar (NA)), selective agar-treated cetrimide (Pseudomonas (cetrimide) agar) and agar-treated Bacillus cereus environments were prepared. Bacterial suspensions for the crop were prepared: 1:10, 1:100, 1:1000, 1:10000, 1:100 000, 1:1 000 000, 1:10 000 000, 1:100 000 000, 1:1.000 000 000, 1:10 $000000000.0 .1 \mathrm{ml}$ of each suspension was poured onto the surface of the environment in Petri dishes and rubbed in with a spatula. Inoculum was incubated for $2-4$ days at $+28^{\circ} \mathrm{C}$.

Isolated bacteria were identified by their morphological, biochemical and physiological characteristics and compared to data in scientific literature. 'Bergey‘s Manual of Systematic Bacteriology’ was used [29].

\section{Results and discussion}

The bioload is one of the main elements of the biofilter. Prior to conducting research, it is extremely important to analyze the load's composition, upon which the bioload's physical properties, affecting the biological breakdown process effectiveness, depend. One of these properties is the bioload's porosity and capillarity. It has been determined that the higher the material's porosity, the faster is the rate of absorption from polluted air [30]. Moreover, a higher porosity of the material means that the bioload's capillary moistening is more effective. As a result, the biodegradation process becomes more effective due to a high bioload porosity and effective capillarity.

Examining the structure of the materials it was determined that a bigger part of the non-woven material consisted of small threads, their width being from 15 to $25 \mu \mathrm{m}$. Gaps between the threads are five to ten times wider than the threads' width (left side of Fig. 3 A). Such thread arrangement allows the formation of a biofilm, avoiding anaerobic zones harmful for the microorganisms. A chaotic thread arrangement allows increasing the material's specific surface area, as well as the biomedium's volume in the material. Zooming in the material 500 times $120-180 \mu \mathrm{m}$ width threads, creating $10-30 \mu \mathrm{m}$ capillary (right side Fig. $3 \mathrm{~A}$ ) are spotted. Thermally processed birch fiber also has a non-even surface, porous structure, and a larger specific surface area (Fig. 3 B). As it can be seen, the birch wood fiber is composed from a number of tiny "straws", aligned parallel to one another, and having a width of $15-30 \mu \mathrm{m}$. Wood fiber is needed in the load to allow microorganisms present in the biomedium to assimilate organic coal, found in it. 

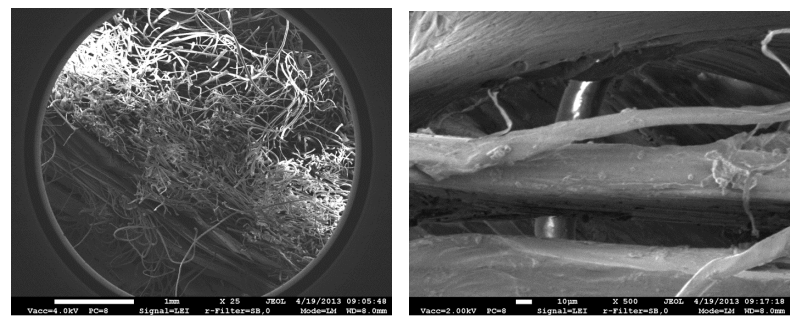

A
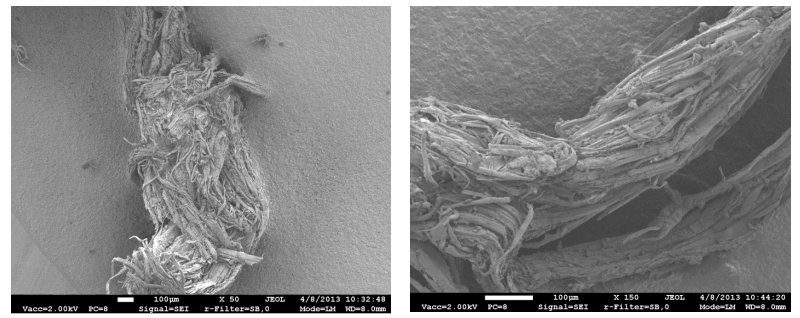

B

Fig. 3. A - nonwoven caulked structure, on the left - increase 25 times, 500 times on the right, $\mathrm{B}$ - birch wood fiber structure on the left - Increase to 50 times, 150 times on the right

Arithmetical averages of the data from all four measurements, taken throughout all days of the experiment, are presented in figure No. 4.

Analyzing the biological breakdown process when the biofilter was supplied with air, polluted by acetone fumes, the biomedium's pH reached 6.1 and gradually increased during the experiment. It reached 7.52 on the seventeenth day of the experiment. Starting from the $17^{\text {th }}$ day the $\mathrm{pH}$ has stabilized, fluctuating between 7.48 and 7.67 . An optimal $\mathrm{pH}$ is in the range of 6 to 8 . Thus, revising the $\mathrm{pH}$ results, obtained during the experiment, it can be stated that the medium's $\mathrm{pH}$ was well-balanced. When air, polluted with xylene fumes, was supplied through the filter, from the $30^{\text {th }}$ to the $38^{\text {th }}$ day, the $\mathrm{pH}$ measurement fluctuated from 7.53 to 7.57 . Viewing the results, obtained during the experiment, and comparing them to the results, obtained by American scientists, according to which the $\mathrm{pH}$ reached 7.0, and the pollutant, filtered by the biofilter was toluene, which has a similar molecular structure to xylene, it can be stated that the pH value was optimal and suitable for microorganisms' proliferation [31].

Chinese scientists, researching toluene-polluted air purification by the means of the biofilter, have determined that the $\mathrm{pH}$ value fluctuated from 7.0 to 7.5 [32]. As already mentioned, neutral, weakly alkaline or acidic mediums are used in biological air filtering. In this case, the medium's pH was weakly alkaline and, according to the obtained results (Fig. 4) it can be stated that the medium's reaction didn't change, there had also been no changes in heterotrophic ferment activity and microorganism growth, the pollutant decomposition was not disturbed. A number of other scientists also state that an optimal $\mathrm{pH}$ value for bacteria growth should reach around 7 [33].

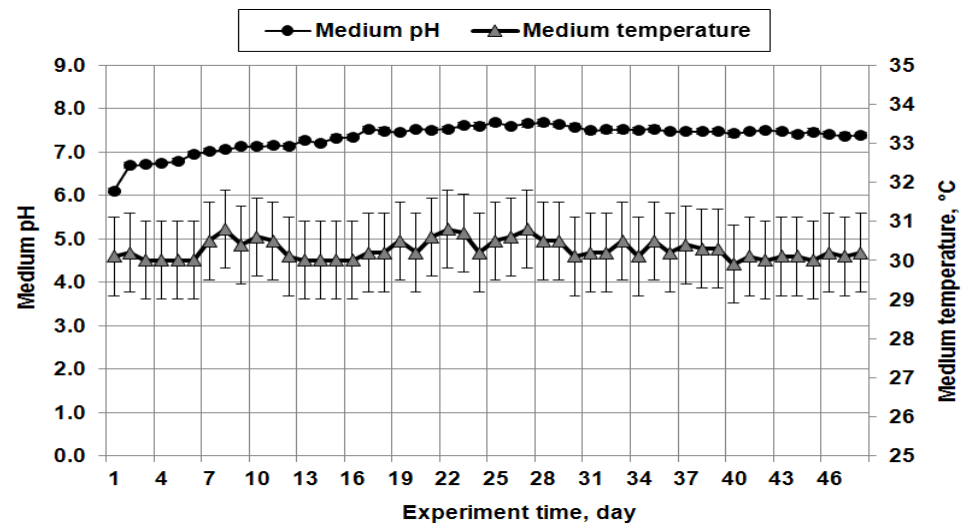

Fig. 4. Medium $\mathrm{pH}$ and temperature $\left({ }^{\circ} \mathrm{C}\right)$ with wavy plates and bio-load of birch wood fibers and nonwoven materials caulked

During the experiment, when air, polluted with ammonia fumes, passed through the biofilter, the measured medium's $\mathrm{pH}$ value was 7.47 on the $39^{\text {th }}$ day and remained around 7.44 during the last part of the experiment (Fig. 4). In this case the medium's pH value was weakly alkaline. Comparing experimental data gathered during our research with data obtained by the Chinese researchers, who used the biofilter to purify air polluted with ammonia and recorded a change in $\mathrm{pH}$ from 7.4 to 8.0 [34], it can be stated that the $\mathrm{pH}$ values recorded during our experiment are adequate. Purifying air, polluted with ammonia, the $\mathrm{pH}$ rate is higher than during other experiments, because it is possible for a part of ammonia to be locked in the medium, thus increasing its $\mathrm{pH}$ value. In low-capacity biofilters mesophillic microorganisms, which have an optimal reproduction temperature of $20-40^{\circ} \mathrm{C}$, are used to decompose volatile organic compounds (VOCs). Bearing in mind this requirement, a temperature of $30^{\circ} \mathrm{C}$ was supported inside the biofilter, as can be seen in Figure 4.

Before starting the exploitation of biological air purification devices, the contained bioload is biologically activated by exposing it to air, polluted with organic contaminants [9]. A bioload is considered to be biologically activated, when it is covered by a thin $(5-30 \mu \mathrm{m}$ thick) biofilm, where microorganisms live.

The effectiveness of the biological air purification process depends on the growth of microorganism cultures in the biomedium. During the initial air purification, when pollutants are supplied to the biofilter, microorganisms are activated, they grow, having an excess of food $[35,36]$. 


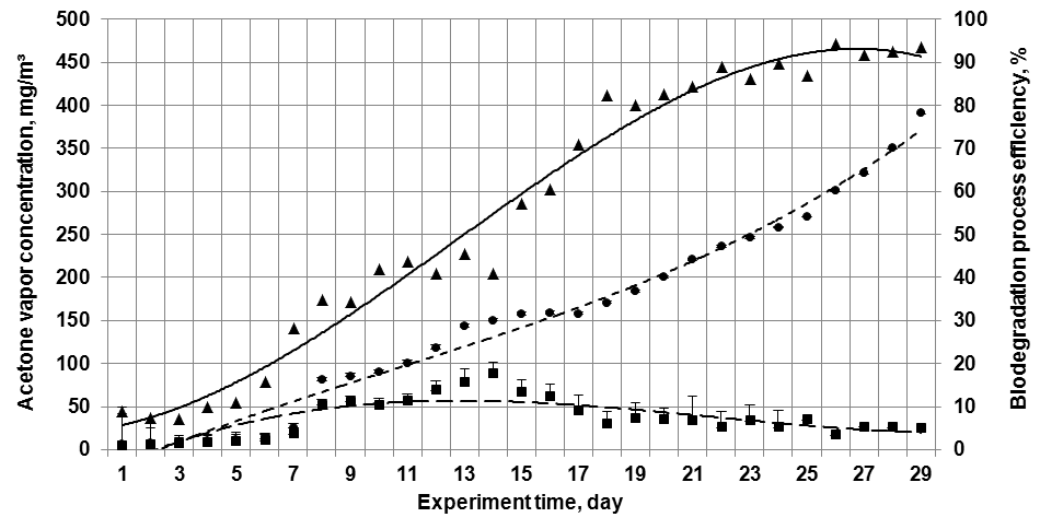

Fig. 5. Acetone concentrations before and after cleaning $\left(\mathrm{mg} / \mathrm{m}^{3}\right)$ and the biodegradation process efficiency when using wavy plate and load the wood fiber with non-woven material caulked: • - acetone concentration before treatment,

$\boldsymbol{-}$ - acetone concentrations after treatment, $\boldsymbol{\Delta}$ - biodegradation process efficiency

The initial acetone concentration was $5.7 \mathrm{mg} / \mathrm{m}^{3}$, in the end of the experiment it reached $390 \mathrm{mg} / \mathrm{m}^{3}$. As we can see in Figure 5, the efficiency of the biological breakdown process gradually increased throughout the experiment's period. The highest air purification efficiency was recorded on the $26^{\text {th }}$ day of the experiment, reaching 94.2\% (Fig. 5). The selfcontained microorganism number reached $1.2 \cdot 10^{4} \mathrm{CFU} / \mathrm{cm}^{2}$ for micromycetes, $11 \cdot 10^{6} \mathrm{CFU} / \mathrm{cm}^{2}$ for bacteria at the beginning of the experiment, and $4.3 \cdot 10^{4} \mathrm{CFU} / \mathrm{cm}^{2}$ for micromycetes and $1.38 \cdot 10^{10} \mathrm{CFU} / \mathrm{cm}^{2}$ for bacteria in the end of the experiment. Penicillium sp., Aspergillus niger, Aureobasidium sp. and Geotrichum sp. types of micromycetes dominated on the surface of porous lamellas. The research results can be compared with the results obtained by other scientists, for example Chang and $\mathrm{Lu}$ (2003), analyzing the biofilter purification efficacy, when filtering acetone-fumes-polluted air. Chang and Lu's results show that the purification efficiency reaches $80-85 \%$, while the acetone fumes concentration in the supplied air reached $175 \pm 10 \mathrm{mg} / \mathrm{m}^{3}$ to $700 \pm 35 \mathrm{mg} / \mathrm{m}^{3}$. In current research, the purification efficiency of $85 \%$ is reached, when the acetone concentration in the air reaches $220 \mathrm{mg} / \mathrm{m}^{3}$.

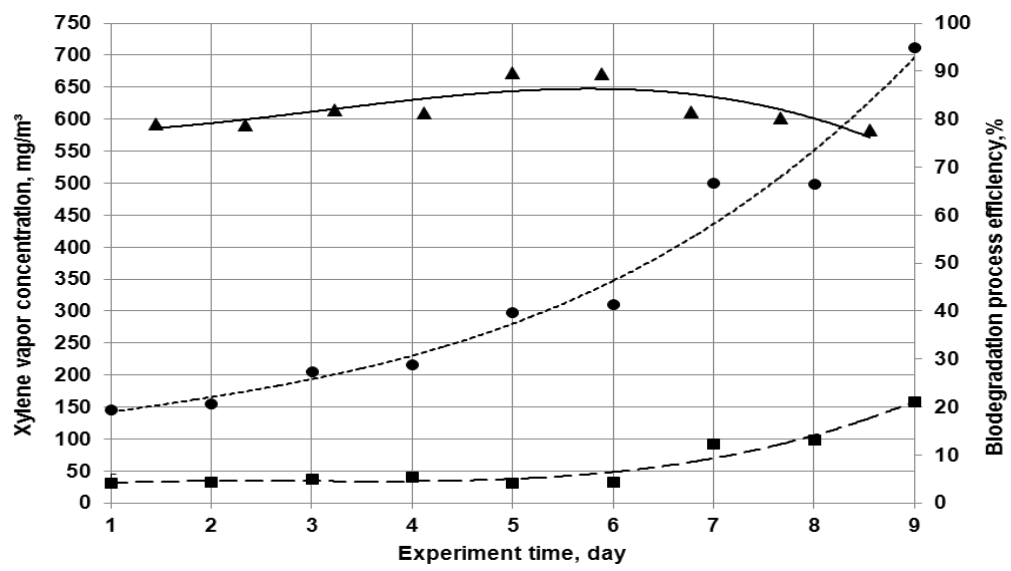

Fig. 6. Xylene concentrations before and after cleaning $\left(\mathrm{mg} / \mathrm{m}^{3}\right)$ and the biodegradation process efficiency when using wavy plate and load the wood fiber with non-woven material caulked: $\bullet$-xylene concentrations before treatment,

- xylene concentrations after treatment, $\boldsymbol{\Delta}$ - biodegradation process efficiency

Experimental research data, when supplying xylene-contaminated air through the bioload, consisting of birch fiber and non-woven caulked material, is provided in Figure 6. The initial xylene fumes concentration in the air supplied to the biofilter was $145.8 \mathrm{mg} / \mathrm{m}^{3}$, reaching $712.5 \mathrm{mg} / \mathrm{m}^{3}$ in the end of the experiment. As we can see in Figure 6 , the biofilter's air purification efficiency gradually increased up to the 5th day of the experiment, reaching $89.7 \%$. Further increasing the pollutant concentration in the supplied air, the biofilter's air purification efficiency declined until the end of the experiment. The biofilter's air purification efficiency of $78 \%$ was recorded, when the supplied air had the highest pollutant concentration $-712.5 \mathrm{mg} / \mathrm{m}^{3}$. The change in the microorganism growth was also measured during the experiment. The micromycetes number changed from $5.6 \cdot 10^{4}$ to $2.2 \cdot 10^{5} \mathrm{CFU} / \mathrm{cm}^{2}$, from $6.8 \cdot 10^{6}$ to $2.45 \cdot 10^{8} \mathrm{CFU} / \mathrm{cm}^{2}$ in bacteria, and $2.9 \cdot 10^{4}$ to $3.9 \cdot 10^{4}$ $\mathrm{CFU} / \mathrm{cm}^{2}$ in yeast. Types of micromycetes remained similar to when acetone was filtered. Further on, Paecilomyces variotii fungi and Aureobasidium and Geotrichum yeast cultures dominated.

Japanese scientists Jeong et al. (2008) [37] had also conducted research with a biofilter, by filtering concentrations of xylene fumes. Their results show that, with a biofilter capacity of $50 \mathrm{~g} / \mathrm{m}^{3} / \mathrm{h}$, the purification efficiency of $80-85 \%$ is obtained. According to $\mathrm{Wu}$ et al. (2006), researching biofilter purification efficiency, with the device's capacity of 
$50 \mathrm{~g} / \mathrm{m}^{3} / \mathrm{h}$, determined that the xylene biological breakdown process reached the efficiency of $70 \%$. The current research indicated that with the identical biofilter's capacity, the efficiency of the biological breakdown process reached $78 \%$.

While purifying air, polluted with acetone fumes, the efficiency of the biological breakdown process was higher than when xylene fumes were supplied to the filter. It might have been determined by a lower gas solubility in water coefficient. The dependency of gas solubility in a biomedium on pressure is determined by Henry's law [38], which states that the gas solubility in a medium is directly proportional to the gas pressure, when the temperature is constant. Increasing the temperature decreases the gas's solubility in the medium, decreasing the temperature increases it [39].

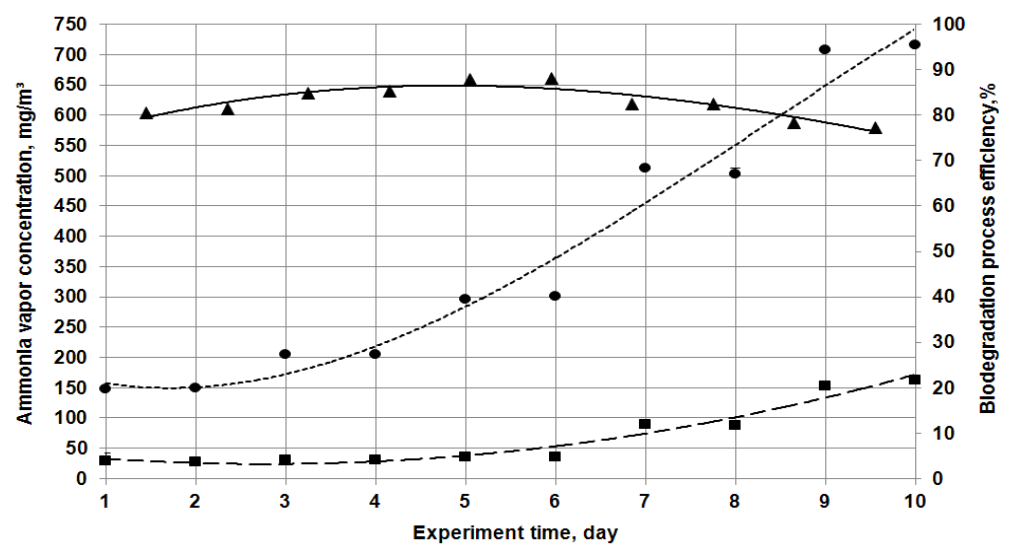

Fig. 7. The ammonia concentration before and after cleaning $\left(\mathrm{mg} / \mathrm{m}^{3}\right)$ and the biodegradation process efficiency when using wavy plate and load the wood fiber with non-woven material caulked: $\bullet$ - ammonia before cleaning

- ammonia concentration after treatment, $\boldsymbol{\Delta}$ - biodegradation process efficiency

In Figure 7 the ammonia concentration in the air supplied to the device and in the expelled air, as well as the dependence of air purification efficiency on time, with the air flow velocity in the bioload being $0.08 \mathrm{~m} / \mathrm{s}$. Research has been conducted with the air flow rate of $1.1 \mathrm{l} / \mathrm{s}$. An increase in the biofilter's air purification is observed during the first six days of the experiment, reaching $88.2 \%$, when the pollutant concentration in the air was $300 \mathrm{mg} / \mathrm{m}^{3}$. Further on, when the pollutant concentration was increased up to $500 \mathrm{mg} / \mathrm{m}^{3}$, the efficiency dropped by approximately $6 \%$, when the pollutant concentration was increased up to $700 \mathrm{mg} / \mathrm{m}^{3}$, the efficiency dropped by approximately $10 \%$. During the experiment, the change in the number of microorganisms was also measured. A change was recorded from $5.0 \cdot 10^{4}$ to $1.8 \cdot 10^{5} \mathrm{CFU} / \mathrm{cm}^{2}$ for micromycetes, $2.4 \cdot 10^{6}$ to $6.4 \cdot 10^{6} \mathrm{CFU} / \mathrm{cm}^{2}$ for bacteria and $3.7 \cdot 10^{4}$ to $1.3 \cdot 10^{5} \mathrm{CFU} / \mathrm{cm}^{2}$ for yeast cultures. Micromycetes types have also changed slightly. Penicillium sp. and not yet fully identified Myrothecium sp., which creates white colonies, joined the previously dominant species. However, Geotrichum sp. and Paecilomyces variotii fungi still remained the dominant species.

The experimental research of wavy lamellas and use of bioload consisting of non-woven caulked material and wood fibres, favorable conditions for growth and reproduction of self-contained microorganisms were created and maintained, therefore, the obtained experimental results can be cross-examined and compared with research results obtained using selected microorganisms. Air humidity reached 70 to $80 \%$, bioload moisture content reached approximately $60-65 \%$, air temperature $26-28{ }^{\circ} \mathrm{C}$, air flow velocity $0.08 \mathrm{~m} / \mathrm{s}$, and the contact time with the biomedium remained the same $-11.25 \mathrm{~s}, \mathrm{pH}$ value reached 7.5 , medium temperature $30 \pm 1{ }^{\circ} \mathrm{C}$.

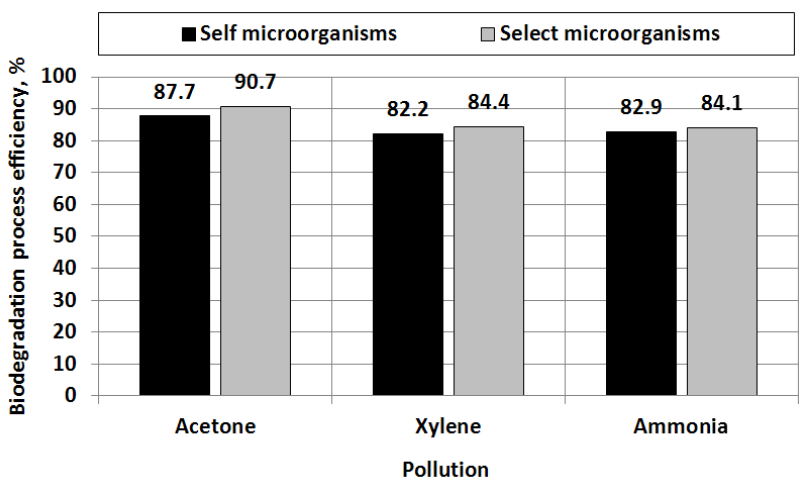

Fig. 8. Biodegradation process of comparison of the effectiveness of the biofilter allowing acetone, xylene and ammonia vapors contaminated air

As can be seen in Figure 8, self-contained microorganisms in the load were better at purifying air, polluted with acetone fumes; when purifying air, polluted with xylene and ammonia fumes, the biological breakdown process efficiency was approximately $82 \%$. When decomposing acetone, xylene and ammonia, bacteria and micromycetes, able to effectively 
decompose volatile organic and non-organic compounds, dominated. The average number of these bacteria and micromycetes was $8.3 \cdot 10^{9}$ and $1.8 \cdot 10^{8} \mathrm{CFU} / \mathrm{cm}^{2}$. After conducting experiments with selected microorganism, capable of decomposing all three pollutants, the biological breakdown process efficiency was 2 to $4 \%$ higher due to a higher number of bacteria, respectively $2.2 \cdot 10^{10} \mathrm{CFU} / \mathrm{cm}^{2}$. The dominant organisms were bacteria: Bacillus subtilis, B. cereus, Pseudomonas putida, P. aeruginosa, P. fluorescens, o mikromicetai: Penicillium sp., Gliocladium viride, Cladosporium herbarum, Geotrichum sp.

\section{Conclusions}

Having analyzed the biodegradation process efficiency, with the bioload consisting of porous polymer lamellas with wood fibers and non-woven caulked material, and the conditions in the biofilter maintained as follows: medium's $\mathrm{pH} 7.5$, temperature $30{ }^{\circ} \mathrm{C}$, bioload's moisture content approximately $65 \%$, humidity in the biofilter around $80 \%$, air temperature $25^{\circ} \mathrm{C}$, air flow velocity between waved lamellas $0.08 \mathrm{~m} / \mathrm{s}$, and the number of self-contained microorganisms: $8.3 \cdot 10^{9}$ $\mathrm{CFU} / \mathrm{cm}^{2}$ for micromycetes, $8 \cdot 10^{8} \mathrm{CFU} / \mathrm{cm}^{2}$ for bacteria, it was determined that a high efficiency of the biological breakdown process, $88 \%$ average when filtering air, polluted with acetone fumes, $82-83 \%$ in the case of xylene and ammonia, was reached using a capillary load moistening system. The efficiency is $2-4 \%$ higher if the selected microorganisms are used for the biological breakdown process, as the number of microorganism colonies is also higher. Using such a moistening system, the load does not need to be mechanically moisturized, thus increasing the energy efficiency. Moreover, a biofilter with a capillary load moistening system is effective to use, when the pollutant fume concentration in the air reaches up to $500 \mathrm{mg} / \mathrm{m}^{3}$, in which case the purification efficiency $80-90 \%$ on average.

\section{Acknowledgements}
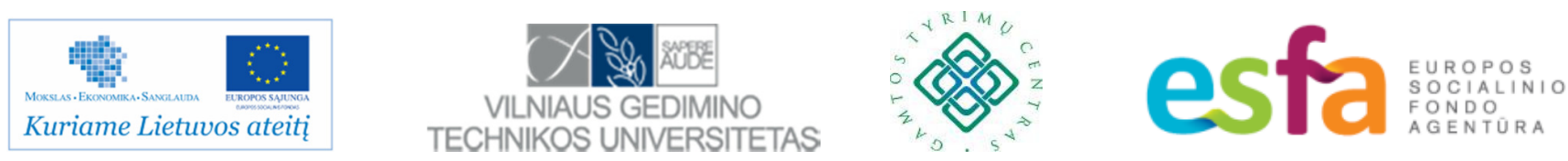

The research is carried out within the framework of project Applied research and technological development of plate type air treatment biofilter with a capillary humidification system for packing material "BIOFILTER" (Project No. VP1-3.1ŠMM-10-V-02-015) under the Operational Programme for the Development of Human Resources 2007-2013, priority axis 3 "Strengthening researchers abilities", measure VP1-3.1-ŠMM-10-V "Promotion of high level international research". The project is funded by the European Social Fund. The project is supported and co-funded by the European Union and the Republic of Lithuania. Project implementation beginning is in 2013. February 1. Total duration of the project -24 months. The aim of the project is a high-level international research implementation, in order to create more efficient model of plate type air treatment biofilter with a capillary humidification system for packing material.

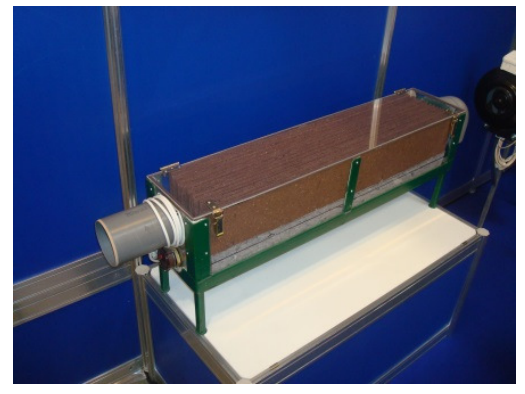

a)

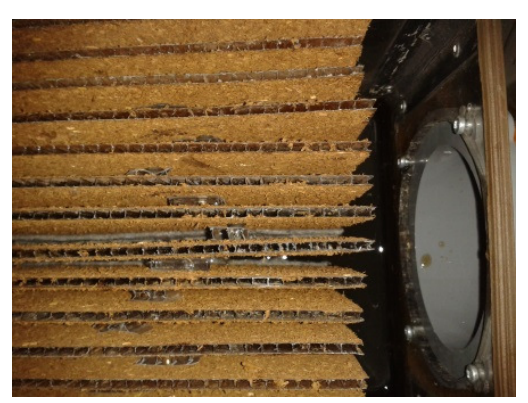

b)

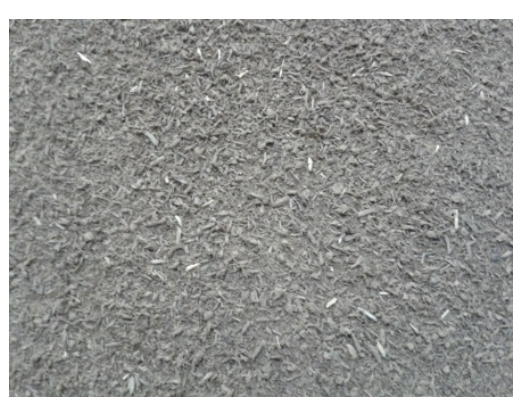

c)

Fig. 9. Biofilter with a capillary humidification system: a - laboratory biofilter stand, b-plate of biofilter, c - surface of plate of wood fiber

The operation principle of the biofilter (Fig. 9a) is based on the decomposition of gaseous pollutants by using certain cultures of microorganisms. The method of biological air treatment employs less expensive, more effective, waste-free and environment friendly biotechnologies which allow more effective cleaning of the air from volatile organic compounds and neutralisation of unpleasant odours.

The main element of the plate type biofilter with a capillary humidification system is a charge. The charge consists of polymer plates arranged vertically next to each other which produce a capillary effect of humidification (Fig. 9b). Due to $2-$ $5 \mathrm{~mm}$ gaps among the plates arranged next to each other the plate type structure of a charge reduces device's aerodynamic resistance. As determined by investigations, the aerodynamic resistance of the biofilter with the aforementioned system of plate arrangement reaches around $10 \mathrm{~Pa}$ and, therefore, fairly long plates can be applied, which enhances the effectiveness of air treatment. 
Lightly pressed boards of thermally processed wood fibre are fixed from both sides of the plates (Fig. 9c). Durability of the wood fibre is achieved through thermal processing of wood waste in a steam explosion reactor (at 32 bar pressure and $235{ }^{\circ} \mathrm{C}$ temperature). Thus, the molecular structure of the wood is changed preventing wood fibre from rot in a humid medium, which extends the durability of biofilter's plates.

Currently, physical and aerodynamic characteristics of biofilters load, treatment efficiency and microbiological studies with introduced microorganisms are being carried out. According to the scientific research, more efficient new generation model of biological air cleaning device, with capillary load irrigation system, will be developed and produced to clean air from volatile gaseous pollutants.

Designed biofilter model will have influence on technological development of science and business companies. Will increase scientists and other researchers mobility and skills. New product will generate greater added value for education institutions and other companies. Industry, livestock farms will be able to increase their production, without breaking pollution controlling restrictions, so the benefits will reach more users. Designed plate biofilter model will be innovative, because of completely new design and load irrigation system, which is based on the capillary effect. The project publicity material has produced dr. Eglè Marčiulaitienè.

\section{References}

[1] Pielech-Przybylska, K.; Ziemiński, K.; Szopa J.St. 2006. Acetone biodegradation in a trickle-bed biofilter, International Biodeterioration \& Biodegradation 57(4): 200-206. http://dx.doi.org/10.1016/j.ibiod.2005.12.005

[2] Paulauskienè, T.; Zabukas, P.; Vaitiekūnas, P.; Žukauskaitè, A.; Kvedaras, V. 2011. Investigation of volatile organic compound (VOC) emission beyond the territory of oil terminals during different seasons, Journal of Environmental Engineering and Landscape Management 19(1): 44-52. http://dx.doi.org/10.3846/16486897.2011.558994

[3] Yang, C.; Chen, H.; Zeng, G.; Yu, G.; Luo, S. 2010. Biomass accumulation and control strategies in gas biofiltration, Biotechnology Advances 28(4): 531-540. http://dx.doi.org/10.1016/j.biotechadv.2010.04.002

[4] Delhomenie, M.; Heitz, M. 2005. Biofiltration of Air: a Review, Critical Reviews in Biotechnology 25: 53-72 http://dx.doi.org/10.1080/07388550590935814

[5] Wu, D.; Quan, X.; Zhao, Y.; Chen, S. 2006. Removal of p-xylene from an air stream in a hybrid biofilter, Journal of Hazardous Materials 136(2): 288-295. http://dx.doi.org/10.1016/j.jhazmat.2005.12.017

[6] Deshusses, M. A.; Cox, H. H. J. 1999. Biotricking filters for air pollution control, Environmental Progress 18(3): 180-196.

[7] Leethochawalit, M.; Bustard, M. T.; Wright, P. 2001. Novel vapor-phase biofiltration and catalytic combustion of volatile organic compounds, Industrial \& Engineering Chemistry Research 40(23): 5334-5341. http://dx.doi.org/10.1021/ie001108q

[8] Devinny, J. S.; Deshusses, M. A.; Webster, T. S. 1999. Biofiltration for Air Pollution Control. Lewis Publishers, NY, USA.

[9] Baltrènas, P.; Zigmontienè, A.; Vaiškūnaitè, R. 2004. Oro valymo biotechnologijos [Biotechnology of air purification], Technika, Vilnius. 205 S.

[10] Khan, F. I.; Ghoshal, A. K. 2000. Removal of volatile organic compounds from polluted air, Journal of Loss Prevention in the Process Industries 13 : 527-545. http://dx.doi.org/10.1016/S0950-4230(00)00007-3

[11] Mudliar, S.; Giri, B.; Padoley, K.; Satpute, D.; Dixit, R.; Bhatt, P.; Pandey, R.; Juwarkar, A.; Vaidya, A. 2010. Bioreactors for treatment of VOCs and odours - a review, J Environ Manag 91: 1039-1054. http://dx.doi.org/10.1016/j.jenvman.2010.01.006

[12] Jankevičius, K.; Liužinas, R. 2003. Aplinkos biologinis valymas [Biological Cleaning of Environmental]. Vilnius: Apyaušris. 342 p.

[13] Yamamoto, T.; Okubo, M.; Hung, Y. T.; Zhang, R. 2005. Odor pollution control, Advanced Air and Noise Pollution Control 2: $273-334$. http://dx.doi.org/10.1007/978-1-59259-779-6_8

[14] Ottengraf, S. P. P.; Konings, J. H. G. 1991. Emissionn of microorganisms from biofilters, Bioprocess Engineering 7: 89-96.

[15] Shareefdeen, Z.; Singh, A. 2005. Biotechnology for Odor and Air Pollution. In: Control Datta, I.; Allen, D. G. Biofilter Technology, Guelph, Canada, $125-145$.

[16] Bibeau, L.; Kiared, K.; Brzezinski, R.; Viel, G.; Heitz, M. 2000. Treatment of air polluted with xylenes using a biofilter reactor, Water, Air, and Soil Pollution 118(3-4): 377-393. http://dx.doi.org/10.1023/A:1005170702783

[17] Pukalskas, A. 2007. Naujausiu moksliniu pasiekimu maisto produktu biotechnologijos srityse moksline studija "Maisto gamybos biotechnologija" [The latest scientific achievements of food biotechnology scientific study "Food production biotechnology"]. Kaunas University of Technology, Kaunas. $55 \mathrm{~S}$

[18] MacNevin, D.; Barford, J. 2001. Inter-relationship between adsorption and $\mathrm{pH}$ in peat biofilters in the context of a cation-exchange mechanism, Water Research 35: 736-744http://dx.doi.org/10.1016/S0043-1354(00)00305-5.

[19] Baltrènas, P.; Zagorskis, A. 2009. Investigation of cleaning efficiency of a biofilter with an aeration chamber, Journal of Environmental Engineering and Landscape Management 17: 12-19. http://dx.doi.org/10.3846/1648-6897.2009.17.12-19

[20] Trejo-Aguilar, G.; Revah, S.; Lobo-Oehmichen, R. 2005. Hydrodynamic characterization of a trickle bed air biofilter, Chemical Engineering Journal 113(2-3): 145-152. http://dx.doi.org/10.1016/j.cej.2005.04.001

[21] Liao, Q.; Tian, X.; Chen, R.; Zhu, X. 2008. Mathematical model for gas-liquid two-phase flow and biodegradation of a low concentration volatile organic compound (VOC) in a trickling biofilter, International Journal of Heat and Mass Transfer 51(7-8): 1780-1792. http://dx.doi.org/10.1016/j.ijheatmasstransfer.2007.07.007

[22] Chang, K.; Lu, C. 2003. Biofiltration of isopropyl alcohol and acetone mixtures by a trickle-bed air biofilter, Process Biochemistry 39: 415-423. http://dx.doi.org/10.1016/S0032-9592(03)00096-7

[23] Wright, W. F. 2005. Transient response of vapor-phase biofilters, Chemical Engineering Journal 113(2-3): 161-173. http://dx.doi.org/10.1016/j.cej.2005.04.009

[24] Dorado, A. D.; Baquerizo, G.; Maestre, J. P.; Gamisans, X.; Gabriel, D.; Lafuente, J. 2008. Modeling of a bacterial and fungal biofilter applied to toluene abatement: Kinetic parameters estimation and model validation, Chemical Engineering Journal 140(1-3): 52-61. http://dx.doi.org/10.1016/j.cej.2007.09.004

[25] Mansour, H. B.; Ghedira, K.; Barillier, D.; Ghedira, L. C.; Mosrati, R. 2011. Degradation and detoxification of acid orange 52 by Pseudomonas putida mt-2: a laboratory study, Environmental Science and Pollution Research 18(9): 1527-1535. http://dx.doi.org/10.1007/s11356-011-0511-7

[26] Baltrènas, P.; Zagorskis, A. 2010. Investigation into the air treatment efficiency of biofilters of different structures, Journal of Environmental Engineering and Landscape Management 18: 23-31. http://dx.doi.org/10.3846/jeelm.2010.03

[27] Pitt, J. I. 1979. The genus Penicillium and its teleomorphic states Eupenicillium and Talaromyces. - London, New York. 634 S. 
[28] Pečiulytè, D.; Bridžiuvienè, D. 2008. Lietuvos grybai. II. Skurdeniečiai (Mortierellales) ir Pelésiečiai (Mucorales) [Fungi of Lithuania. II Mortierellales and Mucorales]. - Vilnius, Publishing office of the Institute of Botany. $256 \mathrm{~S}$.

[29]Garrity, G. M. 2005. Bergey`s Manual of Systematic Bacteriology, in Boone, D.R.; Castenholz, R. W.; Baqnner, D. J.; Krieg, N. R.; Staley, J. T. Michigan, USA. 314 S.

[30] Beyaz, S.; Darkrim Lamari, F.; Weinberger, B.; Langlois, P. 2010. Nanoscale carbon material porosity effect on gas adsorption, International Journal of Hydrogen Energy 35(1): 217-224. http://dx.doi.org/10.1016/j.ijhydene.2009.10.007

[31] Neal, A. B.; Loehr, R. C. 2000. Use of biofilters and suspended-growth reactors to treat VOCs, Waste Management 20(1): 59-68. http://dx.doi.org/10.1016/S0956-053X(99)00297-4

[32] Liu, Y.; Quan, X.; Zhao, Y.; Chen, S.; Zhao, H. 2005. Removal of ternary VOCs in air streams at high loads using a compost-based biofilter, Biochemical Engineering Journal 23(1): 85-95. http://dx.doi.org/10.1016/j.bej.2004.11.002

[33] Mayo, A. W.; Noike, T. 1996. Effects of temperature and pH on the growth of heterotrophic bacteria in waste stabilization ponds, Water Research 30(2): 447-455. http://dx.doi.org/10.1016/0043-1354(95)00150-6

[34] Jun, Y.; Wenfeng, X.. 2009. Ammonia biofiltration and community analysis of ammonia-oxidizing bacteria in biofilters, Bioresource Technology 100(17): 3869-3876. http://dx.doi.org/10.1016/j.biortech.2009.03.021

[35] Deshusses, M. A.; Johnson, C. T.. 1999. Biofiltration of hight loads of ethyl acetate in the presence of toluene, Journal of the Air \& Waste Management Association 49: 973-979. http://dx.doi.org/10.1080/10473289.1999.10463869

[36] Domsh, K. H.; Gams, W.; Anderson, T. H.. 2007. Compendium of soil fungi (Second Edition, taxonomically revised by W. Gams). Eching, IHWVerlag.

[37] Jeong, E.; Hirai, M.; Shoda, M. 2008. Removal of o-xylene using biofilter inoculated with Rhodococcus sp. BTO62, Journal of Hazardous Materials 152(1): 140-147. http://dx.doi.org/10.1016/j.jhazmat.2007.06.078

[38] Miller, M. J.; Allen, D. G. 2005. Biodegradation of $\alpha$-pinene in model biofilms in biofilters, Environmental Science \& Technology 39(15): 5856-5863. http://dx.doi.org/10.1021/es048254y

[39] Miller, M. J.; Allen, D. G. 2004. Transport of hydrophobic pollutants through biofilms in biofilters, Chemical Engineering Science 59: 3515-3525. http://dx.doi.org/10.1016/j.ces.2004.05.011 